\title{
Planning tsunami vertical evacuation routes using high-resolution UAV digital elevation model: case study in Drini Coastal Area, Java, Indonesia
}

\author{
Muh Aris Marfai ${ }^{1} \cdot$ Nurul Khakim $^{2} \cdot$ Hendy Fatchurohman ${ }^{3} \cdot$ Annisa Dzikra Salma $^{1}$ \\ Received: 25 December 2020 / Accepted: 26 August 2021 / Published online: 18 September 2021 \\ (C) Saudi Society for Geosciences 2021
}

\begin{abstract}
Tsunami evacuation is a short process that must be carried out in minutes. Determining the evacuation routes and safe areas is equally important in tsunami evacuation planning. It can be established from least cost distance (LCD) anisotropic model. We use the coastal of Drini, Gunungkidul, Java, Indonesia, as the study area, which is located in a tropical coastal karst region, with a typical karst cone formation. The topographic condition of the karst cone could be an ideal location for tsunami vertical evacuation (TVE). High-resolution orthomosaic images and digital elevation model (DEM) generated from the structure from motion (SfM) process were used as the main data. The tsunami inundation model was calculated based on neighboring operations using raster calculator from the elevation value in the DEM. Land cover identification from high-scale orthomosaic images showed the variation in speed conservation values (SCVs). The slope value was also used as a surface cost that will affect the travel time to the TVE shelters. The results of the model show that TVE is the main alternative in tsunami evacuation planning beside horizontal evacuation. They provide an evaluation of the location of the assembly points and evacuation routes provided by the government, which have been considered ineffective because of the inappropriate model. The results of the study provide an overview of determining the evacuation routes and shelters. Optimum locations can minimize travel time, provide adequate capacity, and be safe from inundation.
\end{abstract}

Keywords Tsunami · Evacuation · DEM · Gunungkidul · Indonesia

\section{Introduction}

Tsunamis are severe catastrophic events that threaten many coastal communities throughout the world. With the longest

Responsible editor: Amjad Kallel

Muh Aris Marfai

arismarfai@ugm.ac.id

1 Department of Environmental Geography, Faculty of Geography, Universitas Gadjah Mada, Sekip Utara Jalan Kaliurang, Bulaksumur, Yogyakarta 55281, Indonesia

2 Department of Geographic Information Science, Faculty of Geography, Universitas Gadjah Mada, Sekip Utara Jalan Kaliurang, Bulaksumur, Yogyakarta 55281, Indonesia

3 Department of Earth Science, Vocational College, Universitas Gadjah Mada, Sekip Unit 1, Jl. Persatuan, Blimbing Sari, Caturtunggal, Kec. Depok, Kabupaten Sleman, 55281 Daerah Istimewa Yogyakarta, Indonesia coastline in the world, and with its location in the "ring of fire," Indonesia is highly exposed to tsunami hazards. The 2004 tsunami event triggered by a 9.1 magnitude earthquake in Sumatra, which killed over 200,000 people, has raised global awareness of tsunamis (Engel and Brückner 2011; Adyan 2008). More than 4.35 million people in Sumatra, Java, and Bali are exposed to the hazard of tsunamis (Post et al. 2009). The southern coast of Java is considered to be the most at-risk area in Indonesia due to its population density and location adjacent to the subduction zone of the Indo-Australian tectonic plates (Hall et al. 2017; Lavigne et al. 2007; Okamoto and Takenaka 2009). The coastal area of Gunungkidul is located on the southern coast of Java. Intensive tourism activities in this regency contribute to increased tsunami vulnerability, and the growing number of tourists has raised the vulnerability level, as more people are exposed to tsunami risk (Marfai et al. 2019). With this increased exposure, evacuation planning must be carefully designed. An effective tsunami evacuation process plays an important role in minimizing loss of 
life, and is categorized into horizontal and vertical evacuations. The vertical evacuation process is one of the shortterm and relatively effective evacuation alternatives to minimize casualties (FEMA P-646 2019; Ashar et al. 2014). In near-field tsunami occurrences, at-risk coastal communities must evacuate immediately due to the short time before the first tsunami wave inundates the coast. During this limited evacuation time, self-initiated evacuations on foot to higher places are considered more effective than with the use of vehicles due to the heavy traffic and possible road damage because of the previous earthquake (Wood et al. 2014). Tsunami vertical evacuation (TVE) is an option for shelter locations during the occurrence of tsunamis. As a short but determining action, which takes place within minutes of a tsunami event, evacuation must be carefully planned and must be supported by effective evacuation routes and accessible higher ground for assembly points.

After the 2004 tsunami event, awareness of tsunami mitigation at the institutional level was significantly raised. The installation of the Indonesian Tsunami Early Warning Systems (InaTEWS), warning signs, and tsunami evacuation routes throughout the coastal areas of Java are expected to reduce casualties (Hall et al. 2017). However, there are many challenges in the evacuation process, including the lack of institutional monitoring, low public understanding and awareness of the tsunami evacuation process, and ineffective tsunami evacuation routes provided by the government. Most of the coastal areas in Gunungkidul Regency are tourist destinations, with a higher percentage of tourists than local communities. Generally, the tourists or visitors have less knowledge of the location of safe places and how to reach them (Takabatake et al. 2017). During an emergency, tourists tend to make critical survival decisions. The existence of tsunami evacuation routes will facilitate people to make the best choices during evacuation. Therefore, an effective evacuation plan must consider both local communities and visitors.

Tsunami evacuation planning requires hazard maps that depict the maximum inundation scenario. However, the main challenge to tsunami hazard modeling is the availability of high-resolution topographic data. The inundation model provided by the government is based on national topographic maps (RBI) with $12.5-\mathrm{m}$ contour intervals, resulting in inaccurate models. These models, which are implemented in most coastal areas of Gunungkidul, lead to ineffective evacuation routes and assembly points. Despite the short evacuation routes with short evacuation time associated with vertical evacuation, the government models suggest horizontal evacuation with long routes to safe areas. However, this issue can be overcome by acquiring remote sensing images using unmanned aerial vehicles (UAVs). Besides providing the latest information at a relatively low cost, the use of UAVs is also suitable for topographic mapping in relatively narrow areas. UAV photogrammetry produces remote sensing images with high spatial resolution and detailed digital elevation models (DEMs) for tsunami hazard modeling (Yan et al. 2009).

The utilization of remote sensing and GIS has broad advantages in disaster analysis. Various problems in hazard mapping analysis can be resolved through the use of DEM data. DEM shows the topographic character of an area which is highly related to physical vulnerability to a disaster. The use of DEM is also in accordance with various types of disasters such as floods, landslides, and erosion (Achour et al. 2018; Uysal et al. 2015)

The objective of this paper is to develop more effective tsunami evacuation planning with a more appropriate model than that provided by the institutional authorities. More advanced data sources and considerations in the model are expected to help decision-makers to identify better tsunami evacuation routes and assembly points for in near-field tsunami hazards. UAV-based topographical mapping was used to generate a tsunami inundation model and to determine safe areas for potential shelters. The model was also used to determine the optimum scenario for vertical evacuation. The results are expected to propose an alternative evacuation system, which in particular is based on vertical instead of horizontal evacuation. The least cost distance (LCD) anisotropic modeling was used in the study to simulate the most effective tsunami evacuation route in relation to the Drini coastal area in Gunungkidul Regency, Java, Indonesia. The coastal karst topography in the area, which consists of cone karst hills, provides potential higher ground TVE locations.

\section{Study area}

Intensive tourism activity in Gunungkidul increases the number of people exposed to tsunami hazard. In the tsunami evacuation scenario, the high number of tourists will have an impact on the effectiveness of evacuation. This study focuses on the coastal area of Drini, Gunungkidul Regency, Java, Indonesia. It is located approximately $60 \mathrm{~km}$ to the southeast of Yogyakarta City (Fig. 1) and consists of several beaches, namely Sepanjang, Watukodok, and Drini Beach. Dry agriculture and agroforestry dominate land use in the area. The built environment is mainly composed of tourist facilities such as shops and lodging; this combination of land use systems will lead to enormous losses if a tsunami occurs. Drini coastal area has an access road as a means of connection between the beaches, whose presence is included in the primary consideration for evacuation planning.

The Drini coastal area is located in the Gunung Sewu karst area, solely lying on the carbonate rocks from the Wonosari Formation (Tmwl). This formation consists of reef limestone, calcarenite, tuffaceous calcarenite, conglomeratic-limestone, marly-tuffaceous limestone, tuffaceous sandstone, and siltstone. According to Kusumayudha (2009), two main 


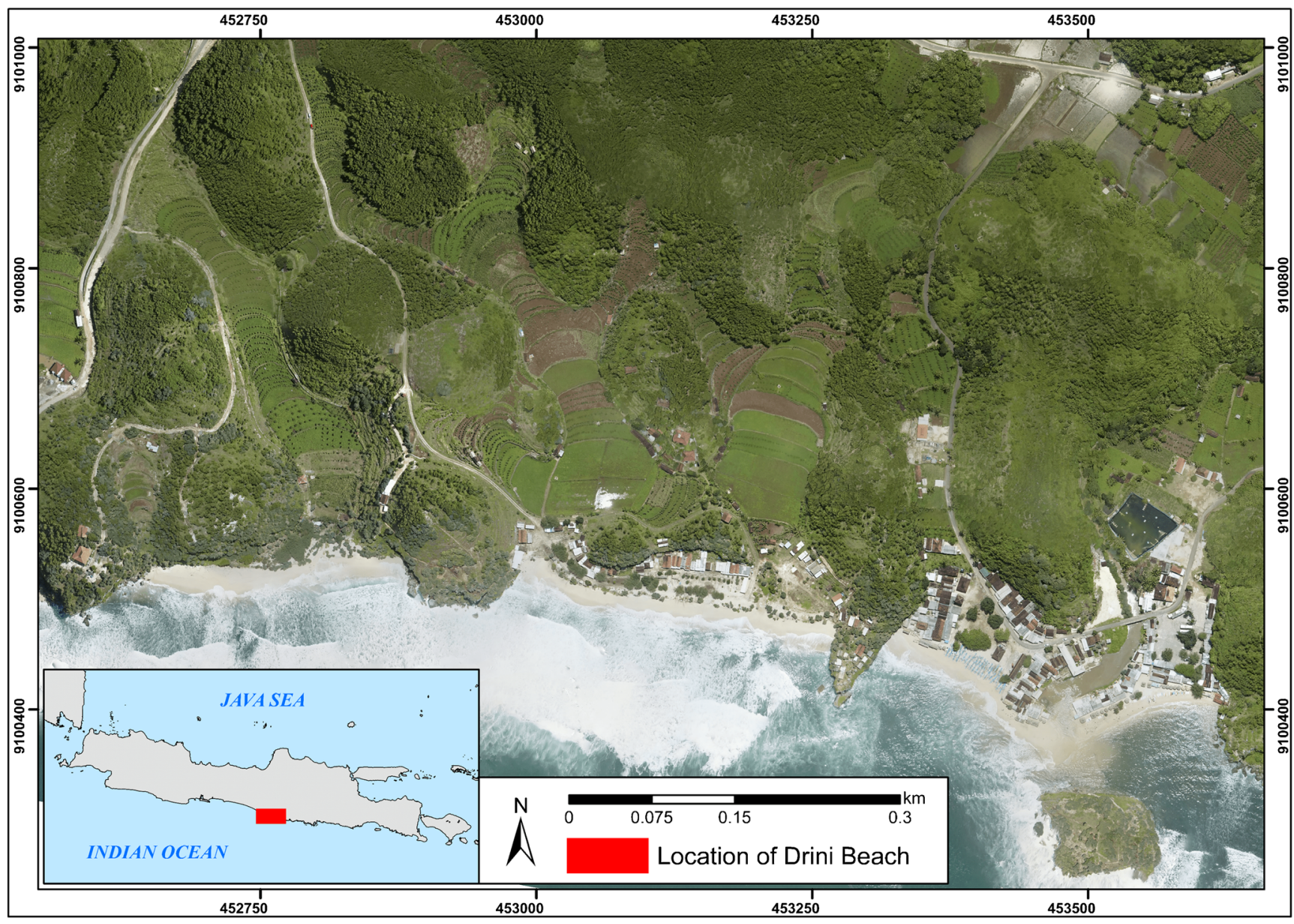

Fig. 1 Location of Drini coastal area

lithofacies, i.e., reefs and bioclastic limestones, are the main constituents in Wonosari Formation with the stratification of the limestone formations incline southward (Fig. 2). Gunung Sewu karst area is also dissected by northwest-southeast faults with a northeast axis syncline in the middle. Haryono and Day (2004) recognized three distinctive landforms based on aerial photograph analysis combined by lineament patterns and field survey, which are labyrinth cone karst, polygonal karst, and residual cone karst. Drini coastal area is located in the labyrinth-cone karst type with rectangular, oval, and straight ridge patterns that are controlled by faults and major joints. The residual hills in this landform type generally have steeper slopes than any other types in Gunung Sewu karst. The role of joints and faults that control the development of labyrinth cones is associated with the subduction zone in the southern part of Gunung Sewu. The maximum compression and stress from tectonic activities form maximum displacement that is indicated by intensive fault and joint.

On most of the Gunungkidul coastline, including Drini, the evacuation sites recommended by the National Disaster Management Agency (Badan Nasional Penanggulangan Bencana (BNPB)) are considered to be too far from the beach and ineffective. The database used by the agency for its modeling was contour data retrieved from a 1:25,000 national topographic map with 12.5 -m contour intervals $(\mathrm{Ci})$. In nearfield tsunami hazards that potentially occur on the southern coast of Java, this evacuation scenario will be ineffective. Tsunami evacuation is a short process that must be prepared with careful planning. Based on the calculation results, sufficient time for the evacuation process in coastal areas in Gunungkidul is around $11 \mathrm{~min}$ (Rosaji 2017). DEM modeling using UAV-based photogrammetry is expected to provide ideal recommendations for temporary vertical evacuation sites.

\section{Methods}

\section{Aerial photo acquisition}

The aerial photographs were taken using a fixed-wing aircraft, mounted with a Canon PowerShot A2500 pocket camera with a resolution of $16 \mathrm{Mpix}$. The camera was set automatically to capture images at 2-s intervals. The flight route was designed at an elevation of $\pm 300 \mathrm{~m}$, and ten markers were placed on the field to represent the distribution of the topographic configuration of the study area. 


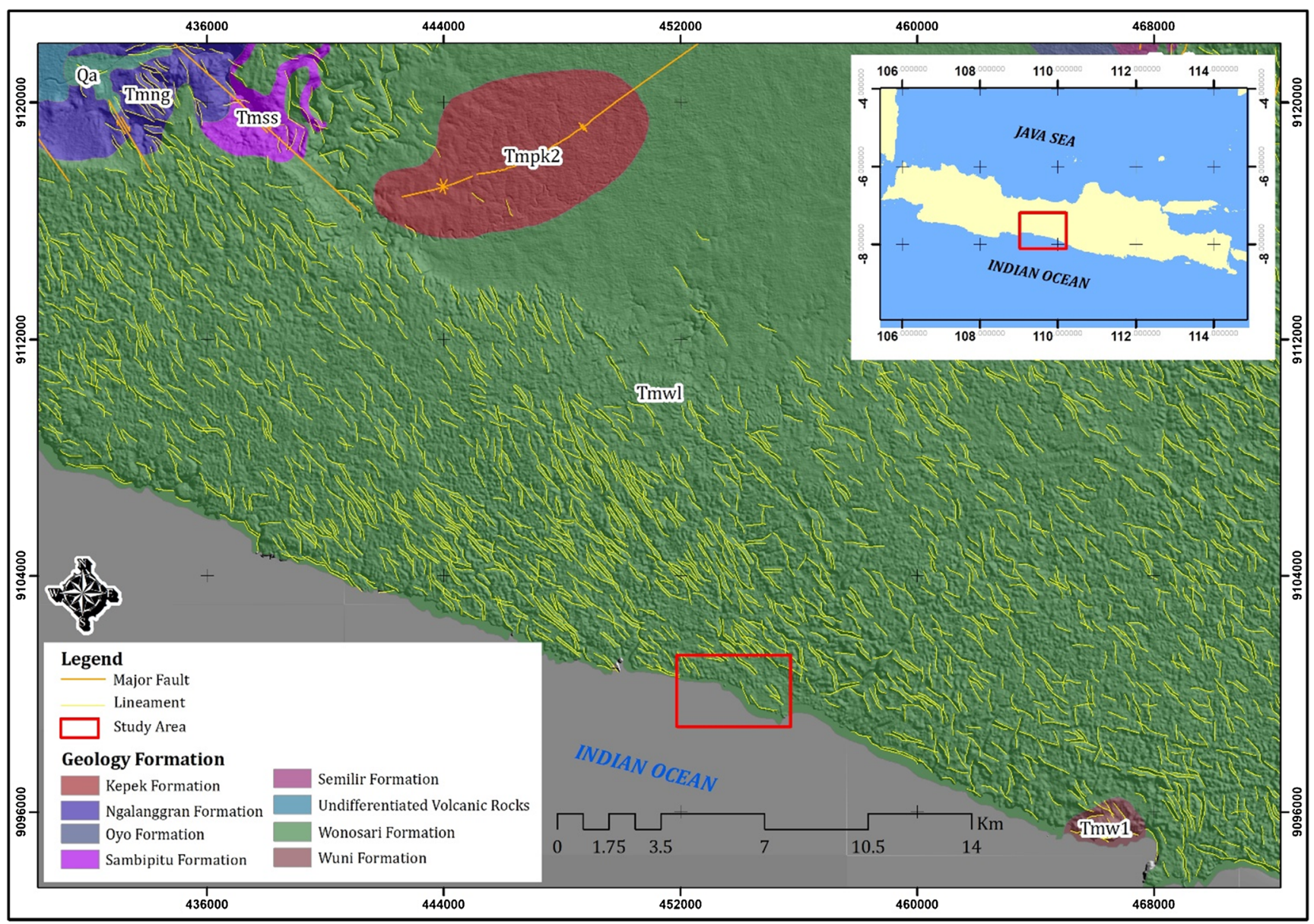

Fig. 2 The geological map of study area

The real-time kinematic (RTK) method was used to acquire the ground control point coordinates. The aerial photograph data acquisition was conducted in March 2017. By providing the most recent DEM data based on aerial photographs, the elevation and land use data are expected to allow more accurate analysis of the inundation model. The UAV-derived photos were processed in Agisoft Photoscan to compute geo-referenced orthophotos and to generate a digital elevation model (DEM), applying the photogrammetric structure from motion (SfM) technical approach. The DEM reconstruction resulting from the SfM orthorectification produced measurements with high precision (Bemis et al. 2014). The study also generated a comparative DEM from the contour lines derived from the digital RBI map $(C i=12.5 \mathrm{~m})$. These contour data were converted to DEM using the spatial analyst tools in ArcGIS 10.5.

\section{Tsunami inundation scenarios}

The study determined various inundation scenarios using the raster calculator in ArcGIS 10.5 by taking into account the maximum historic tsunami height on Java Island, i.e., 11-
13.9 m (Suppasri et al. 2015; BNPB 2011), while Widiyantoro et al. (2020) generate the worst tsunami height scenario for the southern coast of Java, based on potential megathrust earthquake from seismic records and GPS data inversion. Based on their model, the southern coast of Central and East Java has seismic gaps that potentially trigger a Mw 8.8 earthquake. This magnitude will result in $12 \mathrm{~m}$ of tsunami height in some certain places on the southern coast of Java. Therefore, $12 \mathrm{~m}$ of maximum tsunami height was used in this study to determine inundated areas. Based on the worst scenario of a 12-m inundation, raster filtering was performed to select pixels with values less than or equal to $12 \mathrm{~m}$.

A further filtering process was performed to delete polygons that were not hydrologically connected to the shoreline using the "select by location" command. This concept corresponds to the neighboring operation in raster data, in which unconnected pixels are not used in the analysis. The maximum inundation model was recalculated to determine a safe area as an alternative vertical evacuation site. Vertical evacuation sites must be higher than the inundation and possibly on more than one location, such as high ground, hills, or multistory buildings (Ashar et al. 2014; FEMA 2009). The formula used to determine the height of the vertical evacuation site is 
presented in Eq. (1) (Heintz and Mahoney 2008). The locations not inundated by the model were proposed as potential vertical evacuation sites. Several conditions were used to categorize the non-inundated locations as evacuation sites; that is, they should be easily accessible, not in isolated places, and be able to accommodate a large number of people (Trindade et al. 2018).

$H_{\text {min }} V E=H_{\text {run up }}+30 \% \times\left(H_{\text {run up }}\right)+3$ meters

where $H_{\min } V E$ is the minimum height of a vertical evacuation site and $H_{\text {run-up }}$ is the height of the maximum.

\section{Evacuation routes}

The evacuation route was determined using the least cost distance (LCD) model implemented in ESRI ArcMap 10.5 software based on pedestrians walking speed. On foot evacuation is considered the best tsunami evacuation method due to the probable earthquake damage to roads. The evacuation routes were estimated using an anisotropic path distance model where each cell of the rasters has the travel cost. Travel costs were classified as speed conservation values (SCV) that represent every difficulty of traveling through slope and land cover (Jones et al. 2014; Schmidtlein and Wood 2015; Wood et al. 2016, 2018; Wood and Schmidtlein 2012).

The land covers and terrain data were obtained from manual interpretation of UAV orthomosaic and digital surface model (DSM). Land cover was transformed into SCV to estimate the travel times out of the evacuation zone based on Soule Goldman's (Soule and Goldman 1972) terrain energy coefficient categories (Table 1). The lower the SCV value, the slower the travel time to the TVE location. The slope parameter was derived from high-resolution UAV-derived elevation data. Digital terrain model (DTM) was used as elevation data sources and extracted from DSM-UAV using PCI Geomatica software. DTM can represent bare ground without the height of vegetation and man-made features (Hirt 2014). The slope from DTM was transformed into SCV based on Tobler's hiking function (Tobler 1993). The LCD and simulation model estimated the optimum travel direction involving the least cost or least time. The LCD model calculated the travel direction for an evacuation path using the path distance tool. The simulation model estimated the possible path by considering the hazard map (Wood et al. 2016). After the evacuation route was determined from the LCD model, the evacuation scheme is simulated on the field with 12-min time limit. The methodology flowchart of this study is depicted in Fig. 3.

\section{Results and discussion}

Image orthorectification is a preliminary process in creating mosaics from single aerial photographs. In this study, 314 photos were captured for the Drini coastal area and then filtered based on several criteria, including the percentage of overlap, brightness level, and the exclusion of blurred photos. The results of this process were orthophotos and a digital surface model (DSM) with $9 \mathrm{~cm}$ and $45 \mathrm{~cm} \mathrm{GSD}$, respectively (Fig. 4). The threedimensional modeling employing UAV-based photogrammetry produced good accuracy for hydrological analysis, including the tsunami inundation model (Díaz-Vilariño et al. 2016).

There was a very significant difference between the DEMUAV and that created using the contour information from the 1:25,000 RBI map or DEM-RBI. DEM-RBI produced a rough topographic impression that consequently implies to the inundation model. The tsunami hazard map provided by the National Disaster Management Agency uses a basic analysis of the contour data from the national topographic map, which overestimates the inundated areas. Consequently, the assembly or evacuation points as safe areas are not functional. Considering the evacuation time (11 min), these points are too far away for pedestrians to reach.

The accuracy and reliability of tsunami inundation model results are strongly dependent on the accuracy and resolution
Table 1 Speed conservation values for each type of land cover

\begin{tabular}{lll}
\hline Land cover & Terrain energy coefficient categories (Soule and Goldman 1972) & Speed conservation value \\
\hline & & 0 \\
Water body & & 0 \\
Paddy field & Swampy bog & 0.5556 \\
Beach/sand & Hard sand & 0.5556 \\
Heavy brush & Heavy brush & 0.6667 \\
Dry & Light brush & 0.8333 \\
agriculture & Light brush & 0.8333 \\
Ophen space & Dirt road & 0.9091 \\
Road & Asphalt & 1 \\
\hline
\end{tabular}


Fig. 3 The flowchart of evacuation route model determination

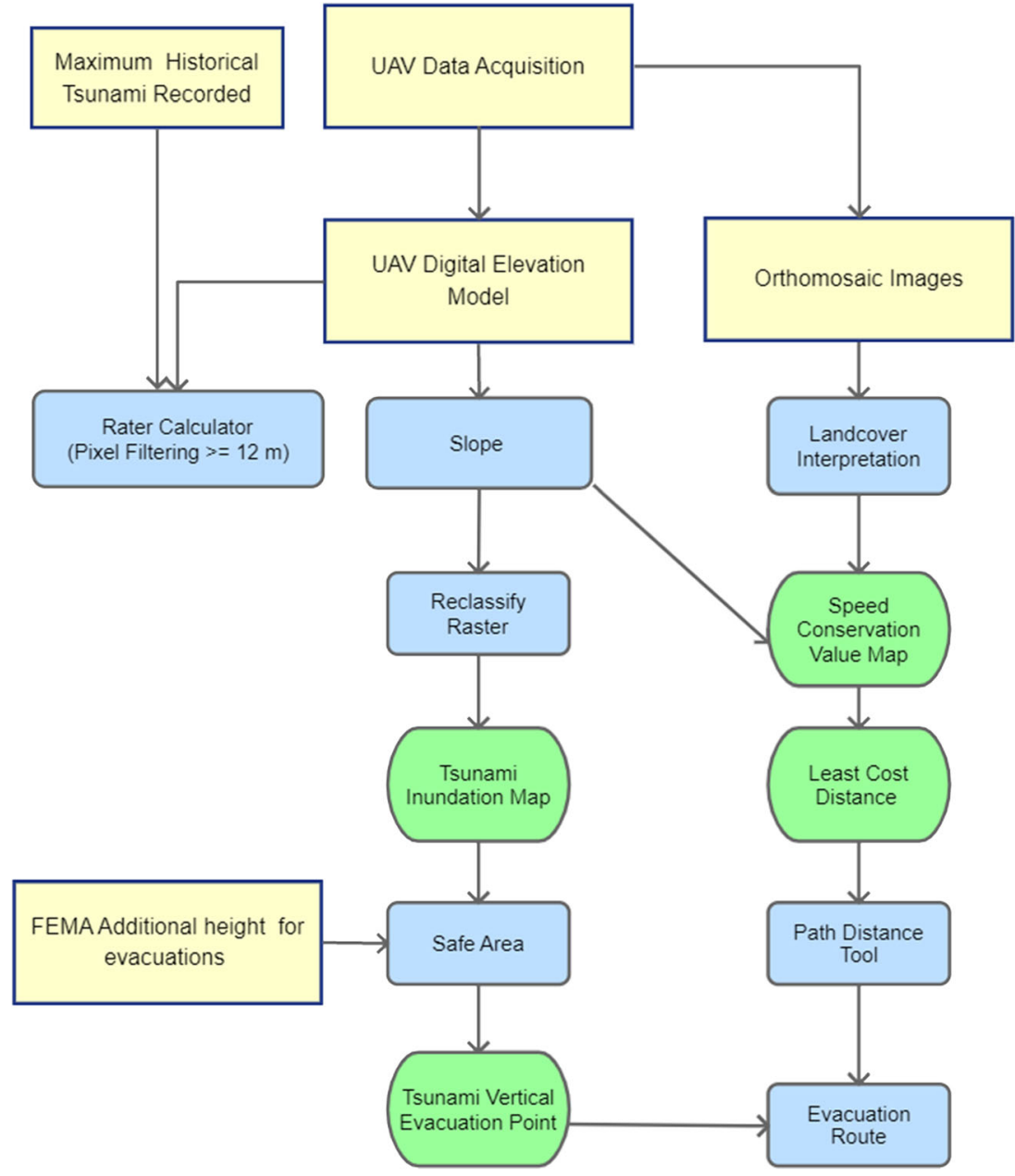

of the data input. The maximum tsunami inundation scenario was modeled with a numerical code that applied to the smallest cell size (Schneider et al. 2016). Therefore, DEM with a high spatial resolution was required to maximize the process on the smallest cell size. DEM-UAV and DEM-RBI showed significant differences regarding the results of the pixel value interpolation. The distribution and the smoothness of the interpolation are obvious in the generated DEM from both sources (Fig. 5).
As a consequence, the maximum tsunami inundation scenario generated from high-resolution DEM-UAV performed a more precise analysis to determine the safe areas. High-resolution models from DEM-UAV can also provide a better estimation of areas that are not affected by tsunami inundation (Schneider et al. 2016). The modeling of the maximum scenario from DEM-RBI and DEM-UAV showed a significantly different extent of the inundated area. The tsunami inundation model using
Fig. 4 Results from a UAV orthomosaic and $\mathbf{b}$ DSM of Drini coastal area
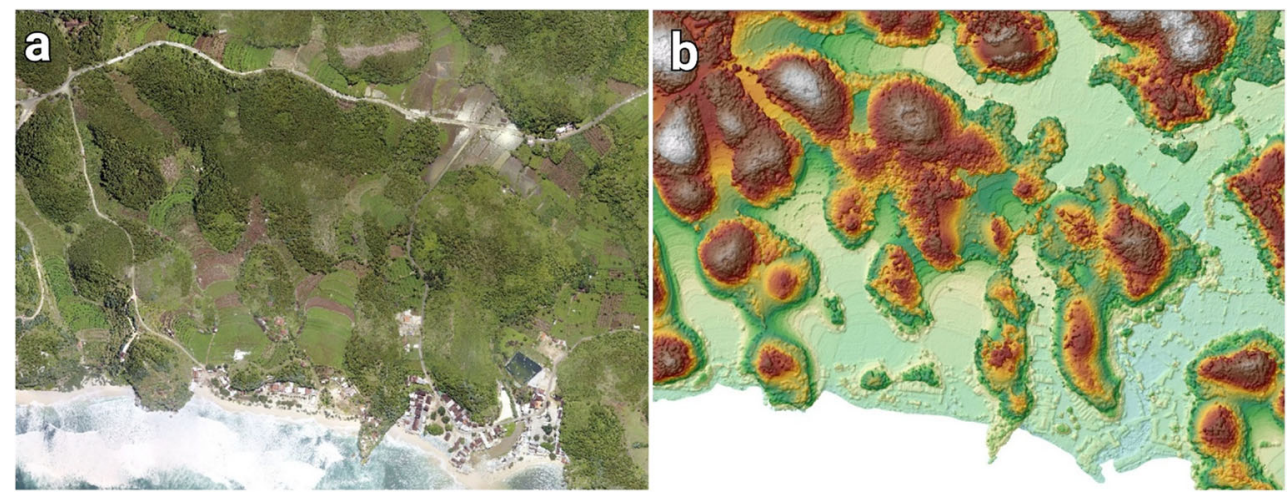


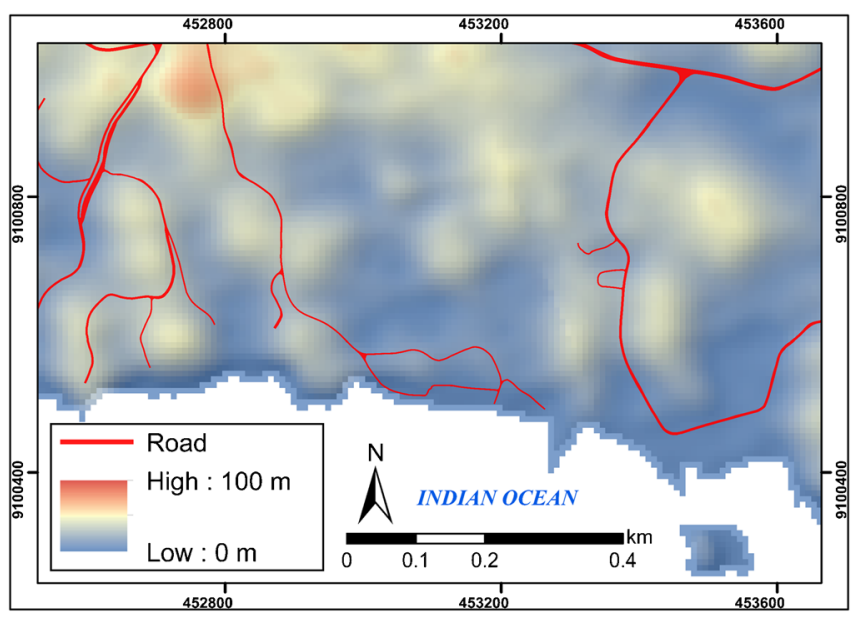

(a)

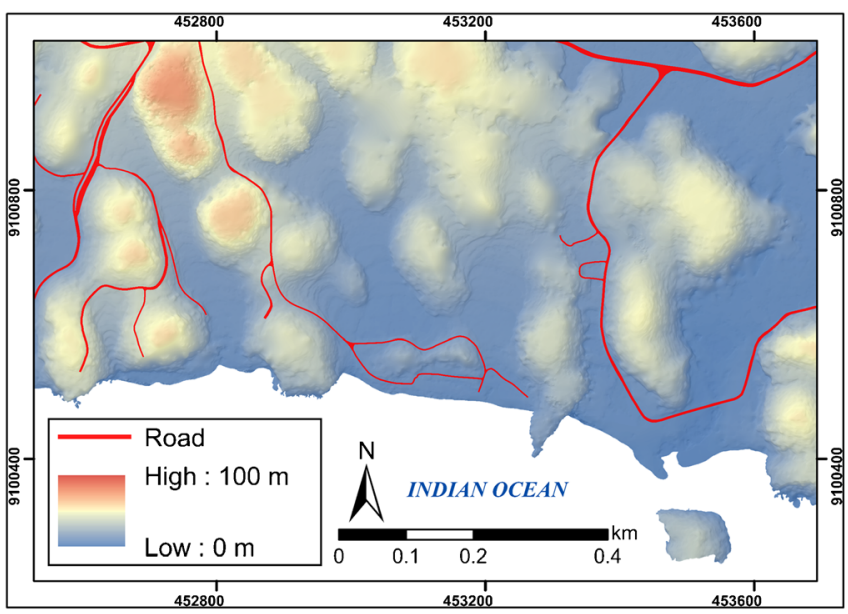

(b)

Fig. 5 Differences between DEM-RBI (a) and DEM-UAV (b)

DEM-RBI produced a rough area, while that using DEMUAV resulted in a much smoother area. Moreover, the distribution of the inundation from the DEM-UAV-based modeling followed the topographic pattern.

The maximum inundation model using DEM-RBI and DEM-UAV resulted in a different extent of inundation and smoothness. The inundation model based on DEMUAV covered a larger area than that using DEM-RBI, the reason being that the execution of the DEM-RBI-based modeling stopped at an elevation of $12 \mathrm{~m}$ because the contour above it was too high. Furthermore, the DEMUAV-based inundation model showed very fine or smooth results. The high spatial and temporal resolution of the UAV-derived data increased the ability to respond to critical conditions in which access to three-dimensional information is crucial (Schneider et al. 2016). In this case, tsunami modeling requires access to $3 \mathrm{D}$ data with a high spatial resolution to maximize the outcome.
The tsunami hazard and evacuation route map provided by the National Disaster Management Agency makes vertical and horizontal evacuations irrelevant. Based on this map, a maximum scenario of a 50-m tsunami was used to determine the safe areas. Therefore, the evacuation plan is irrelevant, considering the maximum allocated time for evacuation is only $11 \mathrm{~min}$. The safe assembly area or safe point on the National Disaster Management Agency's map is $1.6 \mathrm{~km}$ from Drini Beach; at average walking speed, people would take $19 \mathrm{~min}$ to reach the closest evacuation point. Evacuation route and tsunami hazard map are depicted in Fig. 6.

To improve the accuracy of the tsunami inundation model, the digital surface model (DSM) was converted to the digital terrain model (DTM). This conversion aims to remove the land cover so that the tsunami model is not obstructed and shows all inundated locations without land cover intervention. The elevation values on the DTM can differ significantly from those of the DSM by more than
Fig. 6 Tsunami evacuation route (left) and hazard map (right) provided by the National Disaster Management Agency installed around the beach entrance
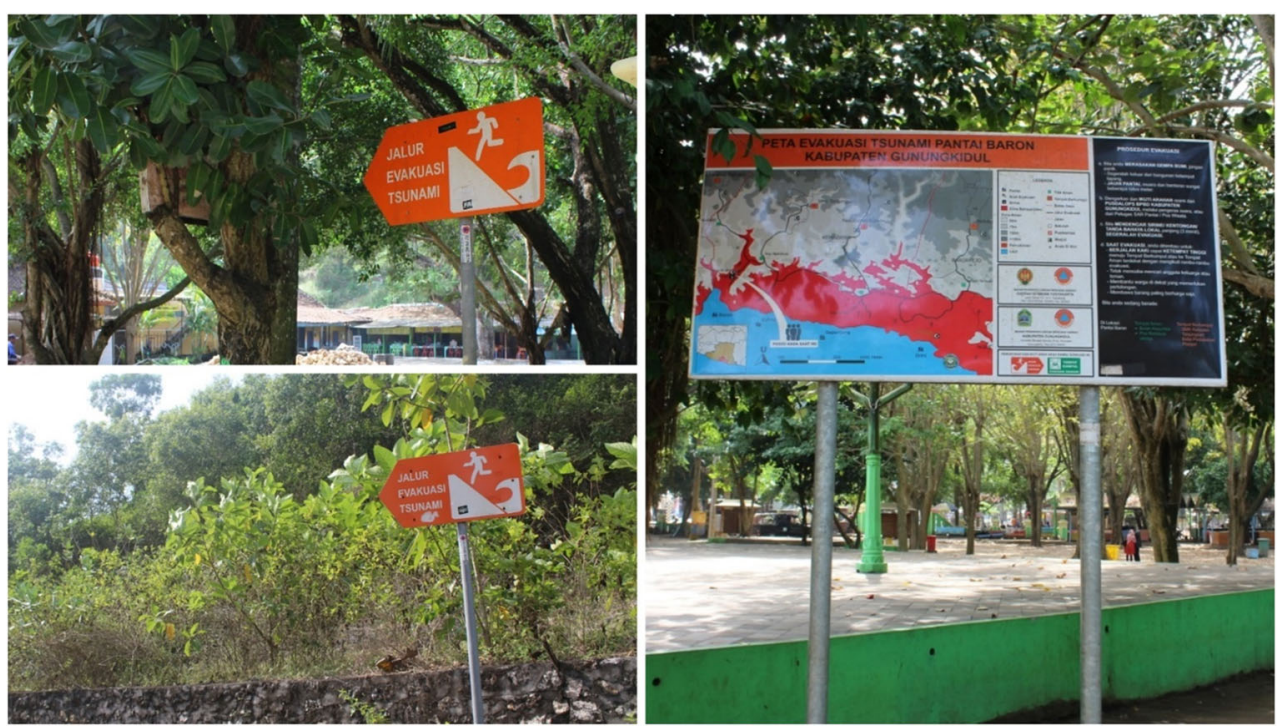

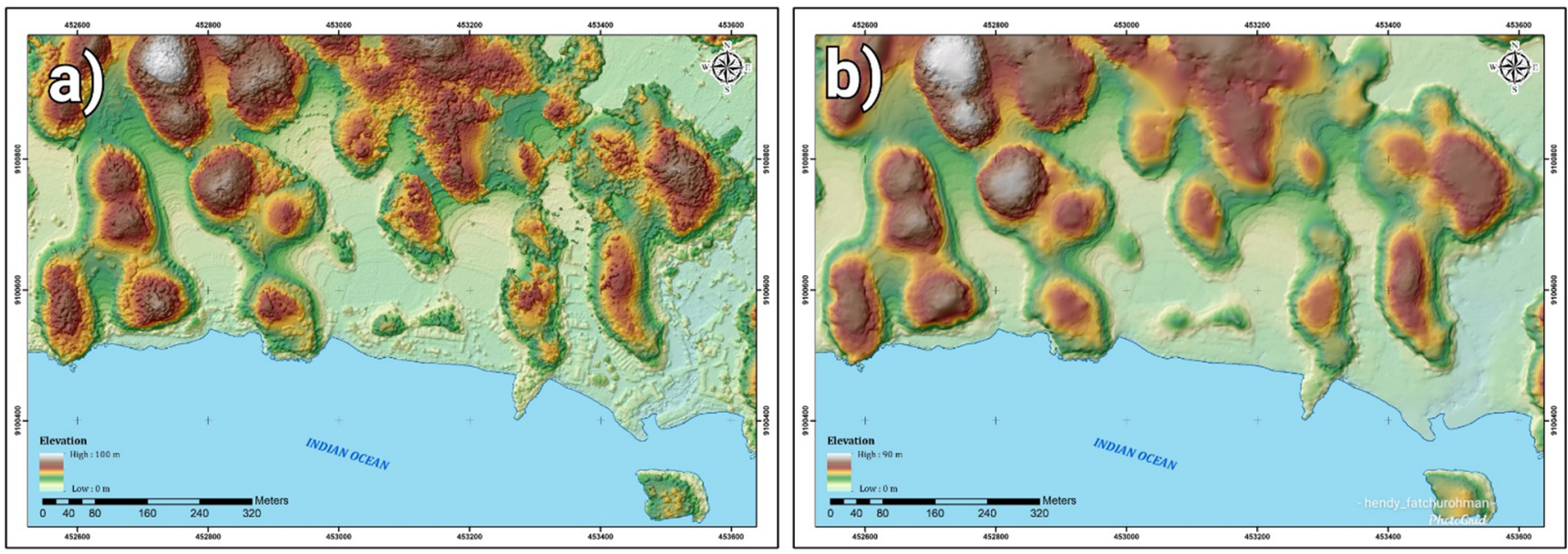

Fig. 7 Digital surface model (a) and digital terrain model (b)

$10 \mathrm{~m}$. The majority of land covers were more than $10 \mathrm{~m}$ high, especially trees and tall shrubs. These land covers can reduce the accuracy of the inundation model and must be removed from the model computation. DSM to DTM conversion was carried out using the PCI Geomatica 14 software through a semi-automatic process. The land cover was delineated and then filtered to get the terrain elevation value. The results of the DSM-DTM conversion are shown in Fig. 7.

The use of UAV mapping for disaster modeling has significantly improved, including hazard emergency response (Gomez and Purdie 2016). UAV-recorded images present actual information with a high rate of data renewal and with higher spatial and temporal resolution. Based on

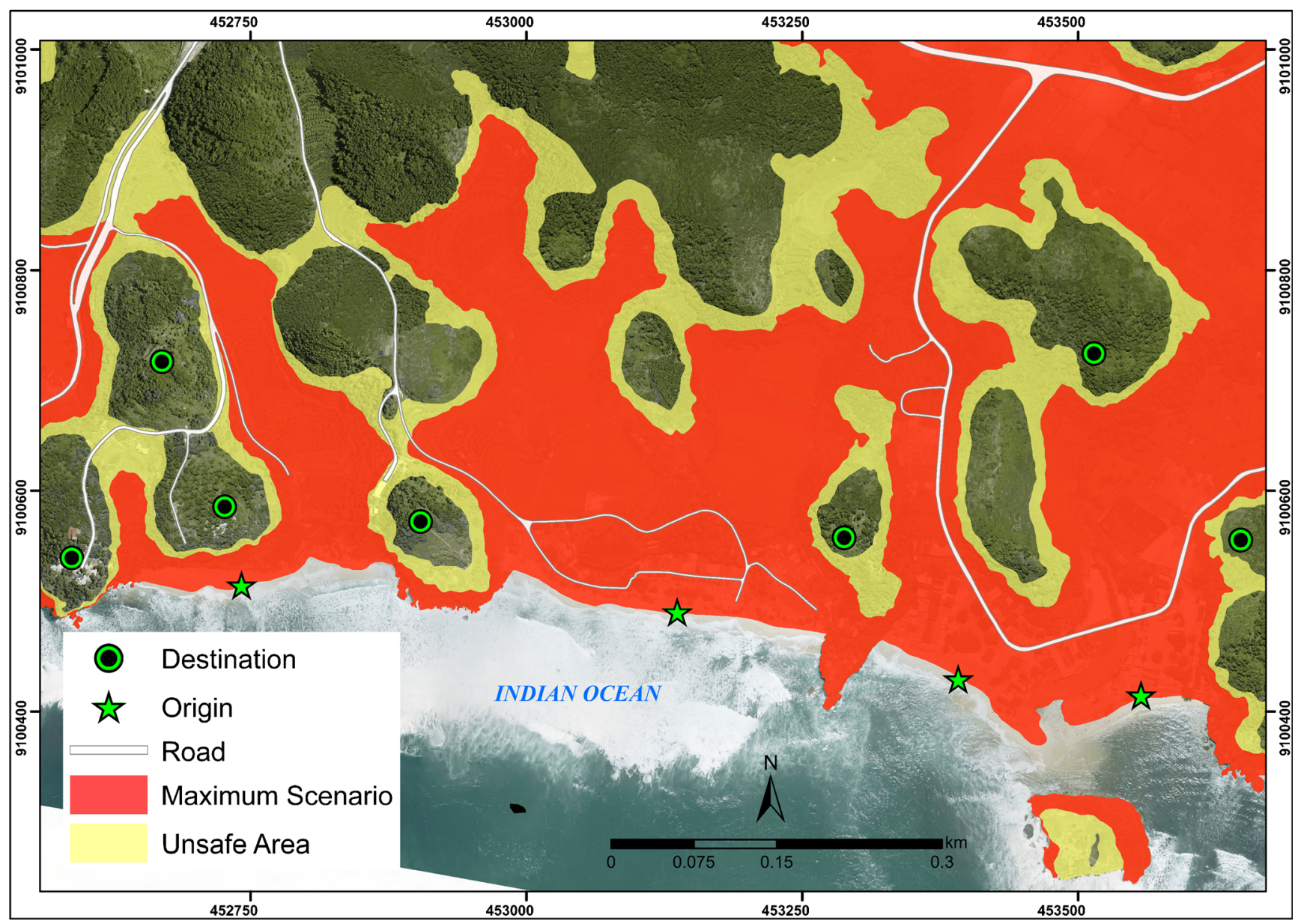

Fig. 8 Unsafe areas indicated by the inundation scenarios and potential TVE 


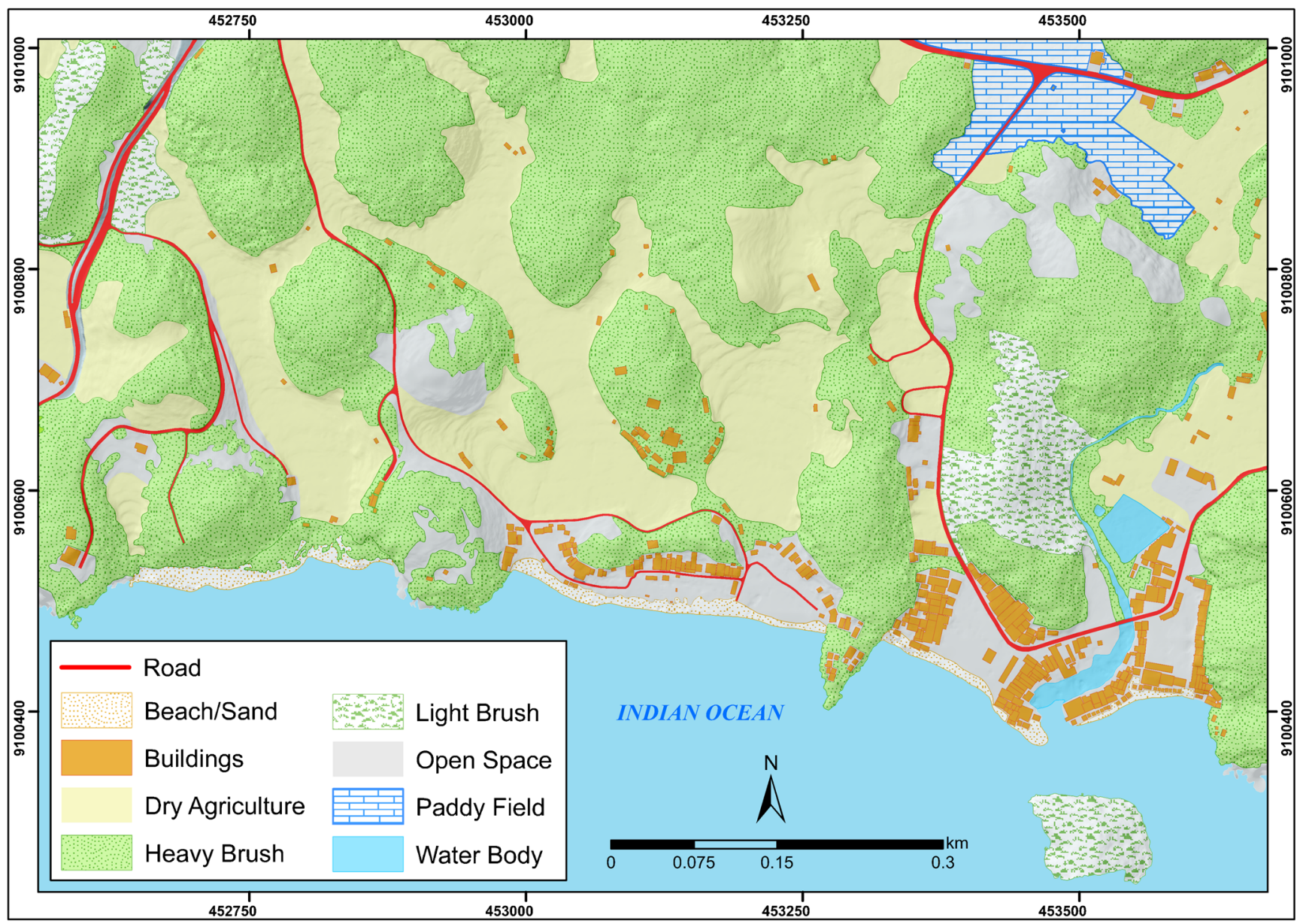

Fig. 9 Land cover map of Drini coastal area

the comparison between DEM-UAV and DEM-RBI (Fig. 5), DEM-UAV has greater reliability as base data for disaster management. Therefore, determination of the vertical evacuation site in this research prioritized the use of DEM-UAV over DEM-RBI. The DEM-UAV-based 3D models are not only accurate for disaster management, but also for describing a detailed topographic impression of the coastal area (Gonçalves and Henriques 2015). Moreover, they can periodically offer an overview of shoreline changes and dynamics, which is vital in identifying the coastline as the starting point of the tsunami inundation scenario. Tsunami inundation modeling tends to use the worst-case scenario to anticipate the exposure of vulnerable areas to any inundation scenarios. This type of modeling can determine the successful implementation of early warning systems and disaster risk reduction (Browning and Thomas 2016).

Based on Eq. (1), the highest inundation was $17.3 \mathrm{~m}$ from the coastline. As determined by DEM-UAV, the maximum scenario used in this research was $12 \mathrm{~m}$. The areas unaffected by tsunami inundation are cone-shaped karst hills that characterize the karstic morphology of Gunungkidul Regency (Adji et al. 2019). Even though karst hills have refraction effects on waves, they tend to be safe and therefore have potential as external evacuation sites (Rosaji 2017). As presented in Figure 8 , the red color on the inundation model shows the maximum scenario of a 12-m tsunami, while the yellow indicates the boundaries of the safe location after the calculation process (Fig. 8). Based on this model, the selection of the vertical evacuation points prioritized sites with access roads. The characteristics of an evacuation zone include accessibility and being a short but safe distance from the inundation and non-isolated areas. The extensive natural cover of shrubs results in the lack of evacuation sites in Gunungkidul coastal area, so the construction of ladders and structural buildings for ideal assembly points on the hills is strongly recommended. Based on the modeling results, six ideal locations are proposed as alternative vertical evacuation sites for Drini Beach and the surrounding areas (Fig. 8).

Each type of land cover results in different travel speeds, according to its SCV; the land cover map of the area is shown in Figure 9. Pedestrian travel time was calculated using the land cover SCV surface derived from terrain energy coefficient categories (Soule and Goldman 1972), slope, and elevation, calculated using the anisotropic path distance tool in ArcGIS. The safe zones were plotted for the location of 
TVE shelters, and evacuation time was converted into minutes.

Besides the land cover, the topographic conditions of the polygonal karst in the Drini coastal area, which consists of karst conical hills, will result in higher surface cost, meaning longer time will be needed. Heavy brush dominates the land cover on the karst hills, attributed with $0.6667 \mathrm{SCV}$. According to the results, the shortest path from the beaches will lead to the closest karst hills located along the beach and provide the fastest route according to the calculation of travel time and SCV.

The evacuation routes that were modeled using LCD calculation showed the shortest path from the beaches to the TVE sites (Fig. 10). However, these routes did not consider if the accessibility is possible and effective for the real situation. Therefore, the evacuation routes were validated on the field with real evacuation simulation. The results from the simulation were used as the validation for the models. The evacuation simulation estimates the possible evacuation routes and assembly points based on the hazard map and considering the time limitation from tsunami warning to the arrival of tsunami waves (FEMA P-646 2019). The time allocation for the evacuation simulation to the safe areas was set into $11 \mathrm{~min}$ of travel time. The near-field tsunami waves are estimated to reach the shoreline in 29 min since the wave generation. The following tsunami early warning will take at least $8 \mathrm{~min}$ after the earthquake. Considering the information dissemination and the chaos, the community is estimated to perform the evacuation after $10 \mathrm{~min}$. Therefore, $11 \mathrm{~min}$ is sufficient time left for the evacuation process (Dewi 2012). The short remaining time for the evacuation requires a short route to make sure that the evacuation succeeds. Assuming a 30-min warning time for the community, with an ambulatory speed of $2 \mathrm{mph}$, FEMA P-646 (2019) estimates that the maximum distance for vertical evacuation sites must be lower than $1 \mathrm{mi}$ and a minimum of $2 \mathrm{mi}$ of distance among the TVE sites.

Seven evacuation routes were simulated to determine whether the $11 \mathrm{~min}$ remaining time is sufficient to reach the safe area. The evacuation was performed using the average ambulatory speed of an adult. Three safe areas were set as the TVE points as the results of the tsunami inundation model (Fig.11). The first route required 6 min of travel time, while the second route required $8 \mathrm{~min}$ to the TVE point. Both routes were simulated to the same TVE destination. The first route

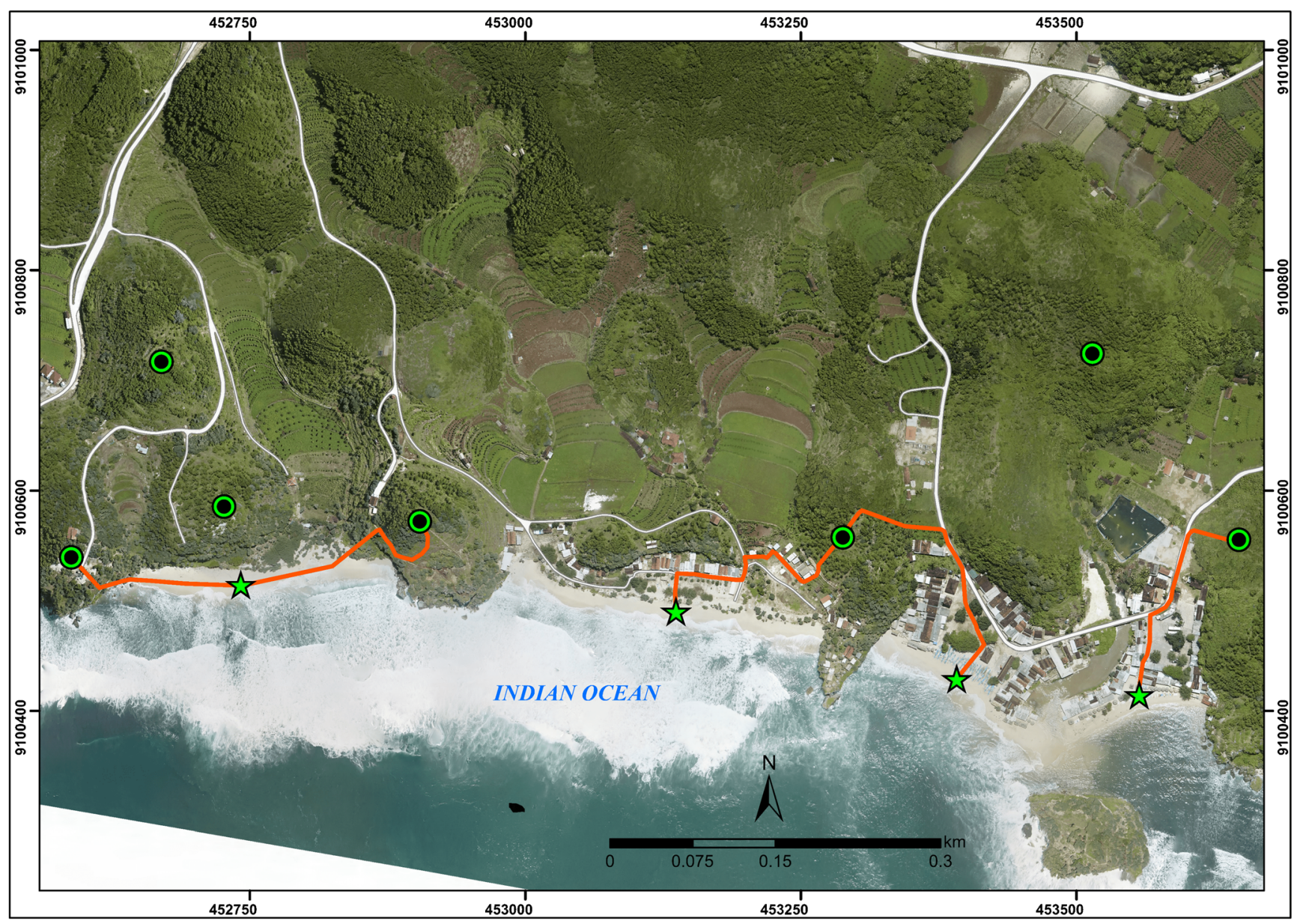

Fig. 10 Tsunami evacuation routes based on least cost distance model 


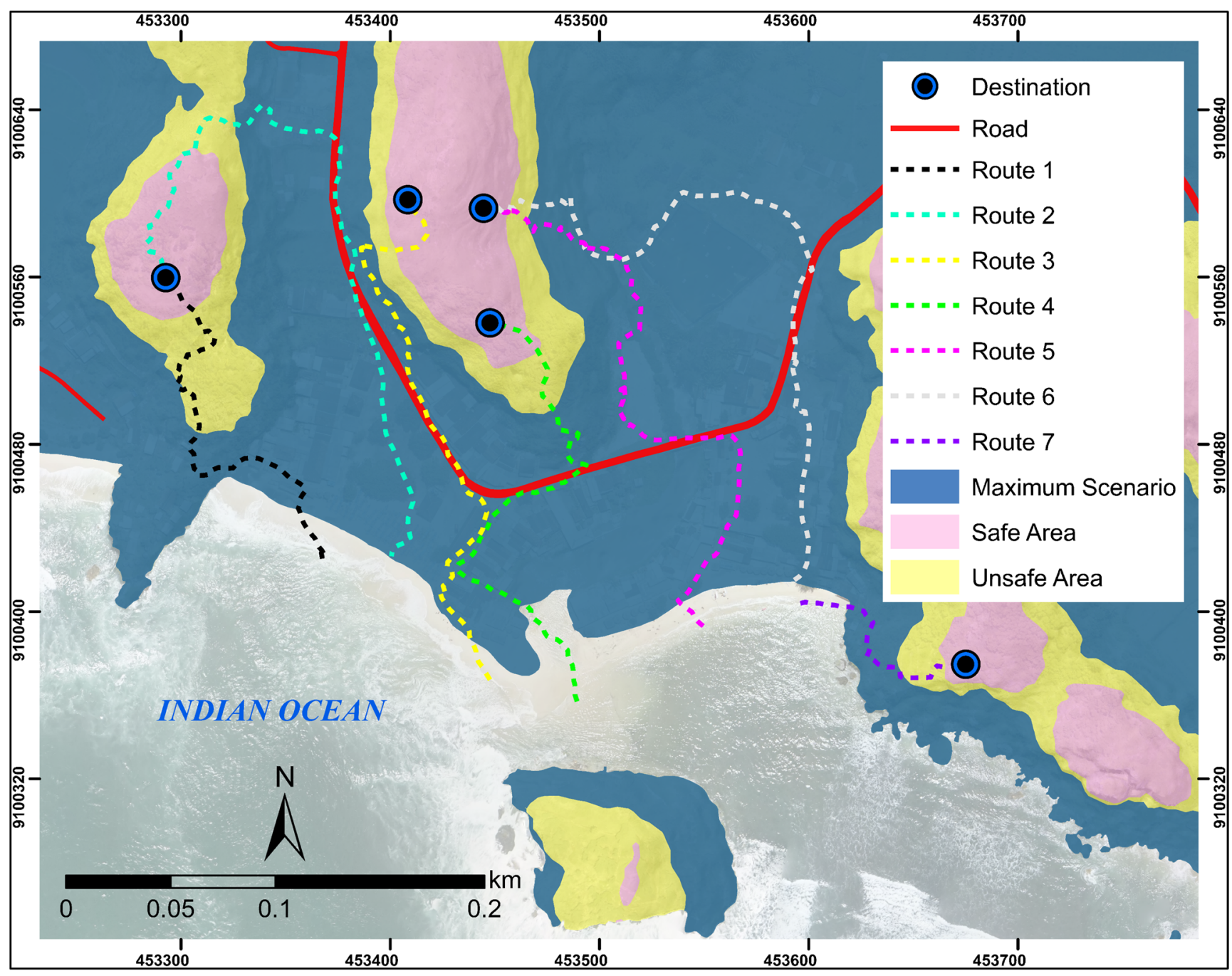

Fig. 11 Tsunami evacuation routes based on field evacuation simulation

provided faster time travel because of the existence of the stairs to the hilltop. These stairs were built to reach the hilltop as a spot for scenic landscape view. Modification of existing high ground for TVE is suggested to accommodate the higher number of evacuees and evacuation success (Cedillos et al. 2010). The third evacuation simulation requires $8 \mathrm{~min}$ from the beach to the TVE site. The fastest route was route number seven, which required only 8 min to reach the TVE site. This site is also provided with stairs to the hilltop. The rest of the simulation takes 8 to $10 \mathrm{~min}$ to reach the TVE sites (Fig. 11).

Despite providing the fastest routes to the TVE sites, routes number one and seven are susceptible to wave erosion or earthquake-induced ground failures because of the steep slopes. If the ground failure occurs, it can obstruct the assembly points' access to ingress and cause evacuees to reroute to other vertical evacuation sites (Wood et al. 2016). The evacuation route numbers two, three, four, five, and six needed a longer time because of the stairs' absence, and most of the routes were covered by bushes. These routes are not recommended for children and the elderly because of the land cover and the steep slopes. This study is preliminary research and requires more detail in providing evacuation planning. Further validation to the model and more alternatives of evacuation points will enhance the accuracy of the model and better evacuation planning. Many travel restrictions during the COVID19 pandemic also became significant disadvantages to the finalization of the project.

\section{Conclusion}

UAV technology is playing an important role in the development of spatial data information in the 4.0 era providing an advanced solution to the development of remote sensing research. In this study, DEM and land use data were generated from UAV photogrammetry and used to model tsunami hazards. These two types of data are accurate and can therefore help predict the extent of inundation and tsunami-affected areas. The DEM data generated from the UAV photogrammetry is far more reliable than DEM-RBI. Tsunami inundation 
modeling in the Drini coastal area is particularly suitable for predicting the extent of tsunami impact and determining safe areas for vertical evacuation. With very short time available for evacuation, vertical shelters become the primary option for saving lives. According to the model, three evacuation points were proposed as the most effective place for TVE. The routes provided by the model did not consider if the accessibility is possible and effective for the real situation. Therefore, the evacuation routes were validated on the field with real evacuation simulation. The shortest route takes $3 \mathrm{~min}$ to reach the evacuation point. The rest of the simulation takes 8 to $10 \mathrm{~min}$ to reach the TVE sites. The data can be further used as the basis for planning evacuation routes and for disaster mitigation. However, the tsunami inundation model in this research requires further improvement because it does not consider the strength of tsunami waves, the time of occurrence, nor the travel time to the safe zones or assembly points. Future research is recommended to take into account these factors in tsunami hazard analysis.

Acknowledgements This research is part of the Excellence Research Grant for Higher Education (Penelitian Dasar Unggulan Perguruan Tinggi (PDUPT)), titled "Desain Manajemen Evakuasi tsunami Menggunakan Integrasi Data Detail Unmanned Aerial Vehicle (UAV) dan Local Knowledge." The authors gratefully acknowledge the research funding and support from the Indonesian Ministry of Research and Higher Education.

\section{Declarations}

Conflict of interest Muh Aris Marfai, Nurul Khakim, Hendy Fatchurohman and Annisa Dzikra Salma declare that they have no conflict of interest.

\section{References}

Achour Y, Garçia S, Cavaleiro V (2018) GIS-based spatial prediction of debris flows using logistic regression and frequency ratio models for Zêzere River basin and its surrounding area, Northwest Covilhã, Portugal. Arab J Geosci 11(18). https://doi.org/10.1007/s12517018-3920-9

Adji TN, Haryono E, Mujib A, Fatchurohman H, Bahtiar IY (2019) Assessment of aquifer karstification degree in some karst sites on Java Island, Indonesia. Carbonates Evaporites 34(1):53-66. https:// doi.org/10.1007/s13146-017-0403-0

Adyan O (2008) Seismic and tsunami hazard potentialsin Indonesia with a special emphasis on Sumatra Island. Journal of the School of Marine Science and Technology, Tokai University 6(3):19-38

Ashar F, Amaratunga D, Haigh R (2014) The analysis of tsunami vertical shelter in Padang City. Proc Econ Finance 18(September):916-923. https://doi.org/10.1016/s2212-5671(14)01018-1

Bemis SP, Micklethwaite S, Turner D, James MR, Akciz ST, Thiele S, Bangash HA (2014) Ground-based and UAV-based photogrammetry: a multi-scale, high-resolution mapping tool for structural geology and paleoseismology. J Struct Geol 69(PA):163-178. https:// doi.org/10.1016/j.jsg.2014.10.007

BNPB (2011) Panduan Nasional Pengkajian Risiko Bencana Tsunami Indonesia. Nat Disaster Manag Agency.
Browning J, Thomas N (2016) An assessment of the tsunami risk in Muscat and Salalah, Oman, based on estimations of probable maximum loss. Int J Disaster Risk Reduction 16:75-87. https://doi.org/ 10.1016/j.ijdrr.2016.02.002

Cedillos V, Canney N, Deierlein G, Henderson S, Ismail F, Syukri A, Toth J, \& Wood K (2010). An evaluation of infrastructure for tsunami evacuation in Padang, West Sumatra, Indonesia. 9th US National and 10th Canadian Conference on Earthquake Engineering 2010.

Dewi RS (2012) A-Gis based approach of an evacuation model for tsunami risk reduction. J Integr Disaster Risk Manag 2(2):108-139. https://doi.org/10.5595/idrim.2012.0023

Díaz-Vilariño L, González-Jorge H, Martínez-Sánchez J, Bueno M, Arias P (2016) Determining the limits of unmanned aerial photogrammetry for the evaluation of road runoff. Measurement: Journal of the International Measurement Confederation 85:132-141. https://doi. org/10.1016/j.measurement.2016.02.030

Engel M, Brückner H (2011) The identification of palaeo-tsunami deposits - a major challenge in coastal sedimentary research. Coastline Rep 17:65-80

FEMA. (2009). Vertical evacuation from tsunamis: a guide for community officials. June, 50.

FEMA P-646. (2019). Guidelines for design of structures for vertical evacuation from tsunamis 3rd Edition (Third).

Gomez C, Purdie H (2016) UAV-based photogrammetry and geocomputing for hazards and disaster risk monitoring-a review. Geoenvironl Disasters 3:23. https://doi.org/10.1186/s40677-0160060-y

Gonçalves JA, Henriques R (2015) UAV photogrammetry for topographic monitoring of coastal areas. ISPRS J Photogramm Remote Sens 104:101-111. https://doi.org/10.1016/j.isprsiprs.2015.02.009

Hall S, Pettersson J, Meservy W, Harris R, Agustinawati D, Olson J, McFarlane A (2017) Awareness of tsunami natural warning signs and intended evacuation behaviors in Java, Indonesia. Nat Hazards 89(1):473-496. https://doi.org/10.1007/s11069-017-2975-3

Haryono E, Day M (2004) Landform differentiation within the Gunung Kidul Kegelkarst, Java, Indonesia. Journal of Cave and Karst Studies 66(2):62-69

Heintz JA, \& Mahoney M (2008). Guidelines for design of structures for vertical evacuation from tsunami. FEMA P646/June 2008.

Hirt C (2014). Digital terrain model. Encycl Geodesy, 1-6. https://doi. org/10.1007/978-3-319-02370-0

Jones JM, Ng P, \& Wood NJ (2014). The pedestrian evacuation analystgeographic information systems software for modeling hazard evacuation potential. In Geological Survey Techniques and Methods, book 11, chap. C9 (p. 25).

Kusumayudha SB (2009) Detecting springs in the coastal area of the Gunungsewu Karst Terrain, Yogyakarta Special Province, Indonesia, analysis using fractal geometry. IPTEK The Journal for Technology and Science 20(4). https://doi.org/10.12962/j20882033. v20i4.86

Lavigne F, Gomez C, Giffo M, Wassmer P, Hoebreck C, Mardiatno D, Prioyono J, Paris R (2007) Field observations of the 17 July 2006 tsunami in Java. Nat Hazards Earth Syst Sci 7:177-183

Marfai MA, Sunarto, Khakim N, Fatchurohman H, Cahyadi A, Wibowo YA, Rosaji FSC (2019) Tsunami hazard mapping and loss estimation using geographic information system in Drini Beach, Gunungkidul Coastal Area, Yogyakarta, Indonesia. E3S Web Conf 76:03010. https://doi.org/10.1051/e3sconf/20197603010

Okamoto T, Takenaka H (2009) Waveform inversion for slip distribution of the 2006 Java tsunami earthquake by using $2.5 \mathrm{D}$ finite-difference Green's function. Earth Planets Space 61:17-20. https://doi.org/10. 1186/BF03352919

Post J, Wegscheider S, Mück M, Zosseder K, Kiefl R, Steinmetz T, Strunz G (2009) Assessment of human immediate response capability related to tsunami threats in Indonesia at a sub-national scale. Nat 
Hazards Earth Syst Sci 9:1075-1086. https://doi.org/10.5194/nhess9-1075-2009

Rosaji FSC (2017). Utilization of unmanned aerial vehicle (UAV) technology for tsunami evacuation planning in coastal tourism areas. Case Study: Pulang Syawal Beach and Its Surroundings, Gunungkidul Regency. Universitas Gadjah Mada.

Schmidtlein MC, Wood NJ (2015) Sensitivity of tsunami evacuation modeling to direction and land cover assumptions. Appl Geogr 56: 154-163. https://doi.org/10.1016/j.apgeog.2014.11.014

Schneider B, Hoffmann G, Reicherter K (2016) Scenario-based tsunami risk assessment using a static flooding approach and high-resolution digital elevation data: an example from Muscat in Oman. Glob Planet Chang 139:183-194. https://doi.org/10.1016/j.gloplacha. 2016.02.005

Soule RG, Goldman RF (1972) Terrain coefficients for energy cost prediction. J Appl Physiol 32(5):706-708. https://doi.org/10.1152/ jappl.1972.32.5.706

Suppasri A, Goto K, Muhari A, Ranasinghe P, Riyaz M, Affan M, Mas E, Yasuda M, Imamura F (2015) A decade after the 2004 Indian Ocean tsunami: the progress in disaster preparedness and future challenges in Indonesia, Sri Lanka, Thailand, and The Maldives. Pure Appl Geophys 172:3313-3341. https://doi.org/10.1007/s00024-015$1134-6$

Takabatake T, Shibayama T, Esteban M, Ishii H, Hamano G (2017) Simulated tsunami evacuation behavior of local residents and visitors in Kamakura, Japan. Int J Disaster Risk Reduction 23(April):114. https://doi.org/10.1016/j.ijdrr.2017.04.003

Tobler W (1993). Three presentations on geographical analysis and modeling - nonisotropic geographic modeling speculations on the geometry of geography and global spatial analysis. Natl Center Geogr Inform Anal Techn Rep 93-1.

Trindade A, Teves-Costa P, Catita C (2018) A GIS-based analysis of constraints on pedestrian tsunami evacuation routes: Cascais case study (Portugal). Nat Hazards 93:169-185. https://doi.org/10. 1007/s11069-017-3152-4

Uysal M, Toprak AS, Polat N (2015) DEM generation with UAV photogrammetry and accuracy analysis in Sahitler hill. Measurement: Journal of the International Measurement Confederation 73:539 543. https://doi.org/10.1016/j.measurement.2015.06.010

Widiyantoro S, Gunawan E, Muhari A, Rawlinson N, Mori J, Hanifa NR, Susilo S, Supendi P, Shiddiqi HA, Nugraha AD, Putra HE (2020) Implications for megathrust earthquakes and tsunamis from seismic gaps south of Java Indonesia. Sci Rep 10(1):1-11. https://doi.org/ 10.1038/s41598-020-72142-z

Wood N, Schmidtlein M (2012) Anisotropic path modeling to assess pedestrian-evacuation potential from Cascadia-related tsunamis in the US Pacific northwest. Nat Hazards 62:275-300. https://doi. org/10.1007/s11069-011-9994-2

Wood N, Jones J, Schelling J, Schmidtlein M (2014) Tsunami verticalevacuation planning in the U.S. Pacific Northwest as a geospatial, multi-criteria decision problem. Int J Disaster Risk Reduction 9:6883. https://doi.org/10.1016/j.ijdrr.2014.04.009

Wood N, Jones J, Schmidtlein M, Schelling J, Frazier T (2016) Pedestrian flow-path modeling to support tsunami evacuation and disaster relief planning in the U.S. Pacific Northwest. Int J Disaster Risk Reduction 18:41-55. https://doi.org/10.1016/j.ijdrr.2016.05.010

Wood N, Jones J, Peters J, Richards K (2018) Pedestrian evacuation modeling to reduce vehicle use for distant tsunami evacuations in Hawai'i. Int J Disaster Risk Reduction 28(November 2017):271283. https://doi.org/10.1016/j.ijdrr.2018.03.009

Yan L, Gou Z, \& Duan Y (2009). A UAV remote sensing system: design and tests BT-geospatial technology for earth observation (D. Li, J. Shan, \& J. Gong, Eds.; pp. 27-44). Springer US. https://doi.org/10. 1007/978-1-4419-0050-0_2, 2010 